Article

\title{
Antiparasitic Properties of Cantharidin and the Blister Beetle Berberomeloe majalis (Coleoptera: Meloidae)
}

\author{
Douglas W. Whitman ${ }^{1}$, Maria Fe Andrés ${ }^{2}$, Rafael A. Martínez-Díaz ${ }^{3}$, \\ Alexandra Ibáñez-Escribano ${ }^{4}$ (D) A. Sonia Olmeda ${ }^{5}$ and Azucena González-Coloma ${ }^{2, *(D)}$ \\ 1 School of Biological Sciences, Illinois State University, Normal, IL 61790, USA; dwwhitm@ilstu.edu \\ 2 Instituto de Ciencias Agrarias, CSIC, Serrano 115-dpdo, 28006 Madrid, Spain; mafay@ica.csic.es \\ 3 Facultad de Medicina, Universidad Autónoma de Madrid (UAM), Arzobispo Morcillo S/N, 28029 Madrid, \\ Spain; rafael.martinez@uam.es \\ 4 Facultad de Farmacia, Universidad Complutense de Madrid (UCM), CEI Campus Moncloa, 28040 Madrid, \\ Spain; alexandraibanez@ucm.es \\ 5 Facultad de Veterinaria, Universidad Complutense (UCM), 28040 Madrid, Spain; angeles@ucm.es \\ * Correspondence: azu@ica.csic.es; Tel.: +34-917-452-500
}

Received: 4 April 2019; Accepted: 18 April 2019; Published: 22 April 2019

\begin{abstract}
Cantharidin (CTD) is a toxic monoterpene produced by blister beetles (Fam. Meloidae) as a chemical defense against predators. Although CTD is highly poisonous to many predator species, some have evolved the ability to feed on poisonous Meloidae, or otherwise beneficially use blister beetles. Great Bustards, Otis tarda, eat CTD-containing Berberomeloe majalis blister beetles, and it has been hypothesized that beetle consumption by these birds reduces parasite load (a case of self-medication). We examined this hypothesis by testing diverse organisms against CTD and extracts of B. majalis hemolymph and bodies. Our results show that all three preparations (CTD and extracts of B. majalis) were toxic to a protozoan (Trichomonas vaginalis), a nematode (Meloidogyne javanica), two insects (Myzus persicae and Rhopalosiphum padi) and a tick (Hyalomma lusitanicum). This not only supports the anti-parasitic hypothesis for beetle consumption, but suggests potential new roles for CTD, under certain conditions.
\end{abstract}

Keywords: cantharidin; blister beetle; Berberomeloe majalis; nematicide; ixodicide; antifeedant

Key Contribution: Cantharidin is active against a diverse range of organisms including protozoa; nematodes; ticks; and insects; supporting the hypothesis that Great Bustards might reduce parasite loads via ingestion of blister beetles.

\section{Introduction}

Cantharidin (CTD) is a toxic trycyclic monoterpene with the chemical formula: 3,6-epoxy-1,2-dimethylcyclohexane-1,2-dicarboxylic anhydride (Figure 1). Found in blister beetles, CTD was one of the first pharmacoactive natural products used by humans [1-3], and was long considered a sexual stimulant [4-8]. In the late Middle Ages, Lytta vesicatoria blister beetles were collected and sold throughout Europe as an aphrodisiac, known as "Spanish Fly" (Figure 2) [9-13]. Today, CTD is used on humans to treat both common and molluscum warts, to remove tattoos, and as a counterirritant, and, until recently, was used as a sexual stimulant in livestock breeding $[4,14]$. Against vertebrates, CTD is a powerful vesicant and highly toxic. However, in low doses it "stimulates" or irritates vertebrate mucus membranes $[10,15,16]$. Human ingestion can result in vomiting, diarrhea, bleeding from the gastrointestinal tract, nephritis, hematuria, proteinuria, liver, kidney and other organ edema and failure, and death [4,16-21]. The consumption of beetles in fresh forage or hay, or drinking beetle- contaminated water, can seriously harm pets, poultry, or livestock $[16,18,22,23]$. 


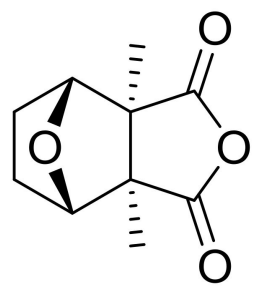

Figure 1. Cantharidin.

Biochemically, CTD acts at multiple levels [16]. It is a potent and specific inhibitor of protein phosphatases 1 (PP1) and 2A (PP2A) [24,25]. It causes the release of serine proteases, which break the peptide bonds in proteins, destroying the adhesion between cells, releasing fluids and causing blistering and bleeding [4]. It disrupts mitosis [16].

CTD was first discovered in blister beetles (Order: Coleoptera; Family: Meloidae), a group of $\sim 3000$ species found in temperate and tropical regions world-wide [16,26]. Most meloids are chemically protected from predators by the presence of CTD, which also plays a role in mating [27]. CTD is transferred from males to females during mating in CTD producing insects [28]. Furthermore, CTD synthesis takes place in the male body and is finally deposited in the testes-hemolymph transport is not involved. In females, CTD enters the genitalia from the male as a nuptial gift [28].
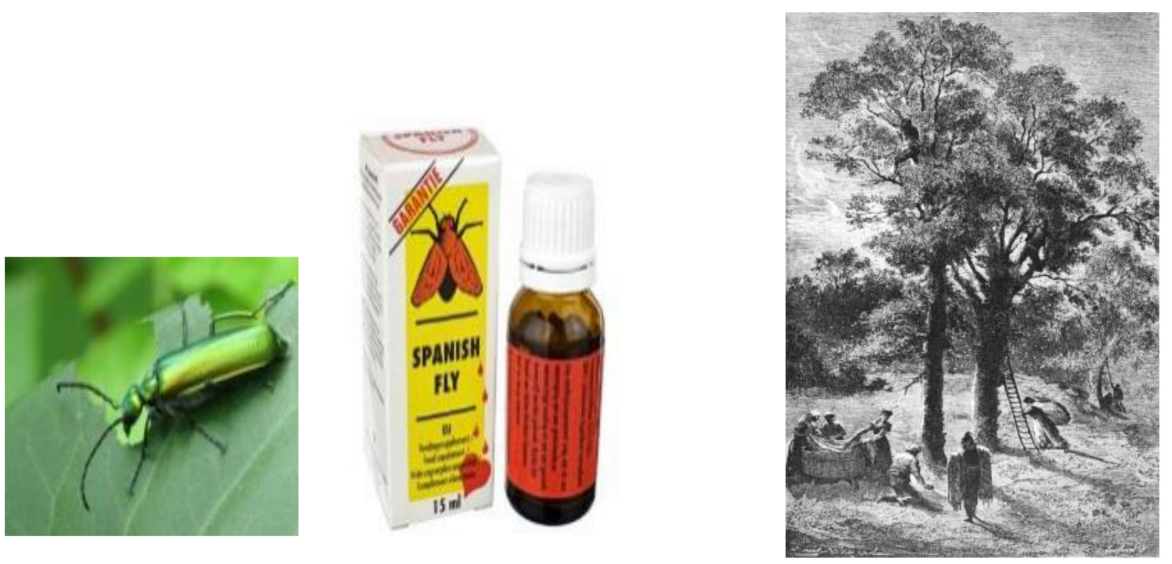

Figure 2. Spanish fly (Lytta vesicatoria) (from Stefanie Hamm), an example of commercial cantharadin preparation, and collecting blister beetles in Spain in the 17th Century.

A few insect predators have evolved partial immunity to CTD and, in some cases, actually use this poisonous substance for their own benefit. Some insects [27], frogs, toads [29], birds [30], and mammals [31] consume them in the wild. Other uses described include the protection of white breasted nuthatches nestholes by sweeping the bark with a meloid insect [32] or traditional pharmacological use by humans [33].

For example, great bustards, Otis tarda, a vulnerable and protected bird species in Europe, consume red-striped oil beetles, Berberomeloe majalis, a common CTD-containing blister beetle in the Mediterranean area, even though the beetle is highly toxic [17,34,35]. Bravo et al. (2014) [36] suggest that beetle consumption by bustards (particularly males) represents CTD self-medication to reduce parasites and diarrhea that impair the appearance of the cloaca of the birds (a central element of courtship), thus increasing their chances of reproduction.

Bravo et al.'s hypothesis is reasonable, considering that CTD is bactericidal [36], and that birds are greatly harmed by a diverse range of pathogens and parasites, including numerous bacteria, protozoa, helminths and arthropods. The protozoans Eimeria spp., Cryptosporidium spp., Giardia spp., Trichomonas spp., Histomonas spp. and Hexamita spp. commonly infect bird digestive tracts [37]. Two protozoa 
cause oropharyngeal diseases in bustards: Trichomonas gallinae and Entamoeba anatis [38]. Cestodes (Hispaniolepis sp., Raillietina cesticillus, Schistometra (Otiditaenia) conoides, and Idiogenes otidis), nematodes (Capillaria sp., Syngamus trachea, Cyathostoma sp., Heterakis gallinae, H. isolench, Aprocta orbitalis, Oxyspirura hispanica, and Trichostrongylus sp), insects (including mallophaga such as Otilipeurus turmalis, and fly maggots such as Lucilia sericata) and ticks (Rhipicephalus sanguineus, and Hyalomma sp.) also infest bustards $[37,39,40]$.

In this paper, we examine Bravo et al.'s (2014) hypothesis [36], by testing the antiparasitic efficacy of both pure CTD and extracts of $B$. majalis beetles against protozoa (Trichomonas vaginalis), a nematode (Meloidogyne javanica), and a tick (Hyalomma lusitanicum). Additionally, several phytophagous insects (Myzus persicae, Rhopalosiphum padi, Spodoptera littoralis) have been tested to include target species other than meloid predators or bird parasites. Our results show strong anti-parasite activity, supporting Bravo et al.'s hypothesis, and suggesting new roles for CTD.

\section{Results and Discussion}

Cantharidin (CTD) concentrations vary greatly between and within Meloid species. Various studies have found from $<0.04$ to $30.3 \mathrm{mg}$ CTD/individual beetles [16,41-43]. Variation in arthropod defense titers is well known [44]. In Berberomeloe majalis the reported CTD content in adults varied between $0.035-1.89 \mathrm{mg} /$ beetle $(0.015-0.845 \mathrm{mg} / \mathrm{g})$ [34] and $1.05-109.2 \mathrm{mg} /$ beetle $(1.5-156.7 \mathrm{mg} / \mathrm{g})$ [36]. Our analysis (Table 1) indicated CTD concentrations of 295 and $41.2 \mu \mathrm{g} / \mathrm{mg}$ in our hemolymph extract and body extract, respectively, indicating that the hemolymph extract was $\sim 7$ times more concentrated in CTD than the body extract. The total CTD contained in 200 insects was $1819 \mathrm{mg}$ (hemolymph + body), giving an estimated value of $9.1 \mathrm{mg}$ of CTD per beetle. These concentrations are within the ranges reported by Bravo et al. (2014) [36]. We detected relatively low amounts of CTD in B. majalis hemolymph as opposed to the beetle bodies (Table 1). This is not surprising, considering that CTD is typically concentrated in meloid reproductive organs [28].

Table 1. Cantharidin (CTD) concentration in Berberomeloe majalis blister beetles and their extracts.

\begin{tabular}{ccccc}
\hline Extract & $\begin{array}{c}\text { CTD } \\
(\boldsymbol{\mu g} / \mathbf{m g})\end{array}$ & $\begin{array}{c}\text { Total CTD } \\
(\mathbf{m g})^{\mathbf{a}}\end{array}$ & $\begin{array}{c}\text { Distribution of Total CTD } \\
\mathbf{( \% )}\end{array}$ & $\begin{array}{c}\text { CTD Per Beetle } \\
(\mathbf{m g})\end{array}$ \\
\hline Body & 41.2 & 1813 & 99.3 & 9.06 \\
\hline Hemolymph & 295.0 & 5.9 & 0.7 & 0.03 \\
\hline Total & - & 1819 & 100 & 9.1 \\
\hline
\end{tabular}

a Total CTD (for $20 \mathrm{mg}$ and $44 \mathrm{~g}$ of hemolymph and body extract respectively). ${ }^{\mathrm{b}}$ Estimated CTD per beetle, $\mathrm{N}=200$ beetles.

Our bioassays demonstrated strong effects from B. majalis extracts and CTD against nearly all species tested. Population growth of the parasitic protozoan Trichomonas vaginalis was strongly suppressed, with 50\% growth inhibition ( $\mathrm{GI}_{50}$ ) at 75.7 (body extract), 15.5 (hemolymph), and $5.6 \mu \mathrm{g} / \mathrm{mL}$ (CTD), with consistent dose-responses (Table 2). CTD had a remarkable activity level in comparison with other natural products and extracts screened against this parasite [45].

Table 2. Activity of cantharidin (CTD) and extracts of Berberomeloe majalis blister beetles against the parasitic flagellated protozoan, Trichomonas vaginalis. Data are expressed as percentages of growth inhibition.

\begin{tabular}{ccccc}
\hline Concentration $(\mu \mathrm{g} / \mathrm{mL})$ & Body Extract & Hemolymph Extract & CTD & Metronidazole \\
\hline 500 & $92.7 \pm 0.8$ & $99.8 \pm 0.3$ & - & - \\
100 & $52.7 \pm 4.6$ & $77.5 \pm 4.1$ & $98.1 \pm 0.3$ & - \\
\hline $\mathrm{GI}_{50}(\mu \mathrm{g} / \mathrm{mL})(95 \% \mathrm{CL})$ & $75.7(24.6-220.2)$ & $15.5(1.4-36.2)$ & $5.6(4.2-7.0)$ & $0.6(0.3-1.4)$ \\
\hline
\end{tabular}


Previously, CTD showed promising effects against Leishmania major, both in vitro, with $80 \%$ growth inhibition at a concentration of $50 \mu \mathrm{g} / \mathrm{mL}$, and in vivo in experimentally infected BALB/c mice $[46,47]$. In addition, norcantharidin and analogs displayed good antiplasmodial activity on sensitive (D6) and chloroquine resistant (W2) strains of Plasmodium falciparum, with $\mathrm{IC}_{50}$ values close to $3.0 \mu \mathrm{M}$ [48]. However, ours is the first report on the effects of B. majalis extracts and cantharidin on Trichomonas sp.

The plant endoparasitic nematode Meloidogyne javanica was also very sensitive to the hemolymph extract, with CTD being extremely potent against this parasite (CTD showed 26 and $>1000$ times more potent $\mathrm{LD}_{50}$ and $\mathrm{LD}_{90}$ values, respectively, than hemolymph) (Table 3). The activity of the hemolymph did not correlate with its content in CTD, may be due to the lipophilic nature of the extract. This is the first report on the effects of B. majalis hemolymph and CTD on nematodes, and specifically on $M$. javanica. Preliminary results on the larvicidal effect of CTD analogs on the parasitic nematode Haemonchus contortus lead to the proposal of serine/threonine phosphatase inhibitors as potential nematicidal targets $[49,50]$.

Table 3. The effects of cantharidin (CTD) and B. majalis extracts on juvenile mortality in the parasitic nematode Meloidogyne javanica.

\begin{tabular}{cccccc}
\hline \multirow{2}{*}{ Treatment } & Dose $(\mu \mathrm{g} / \mu \mathrm{L})$ & Mortality ${ }^{\mathbf{a}} \%$ & \multicolumn{2}{c}{ Lethal Concentrations $^{\mathbf{b}}$} \\
\cline { 3 - 5 } & & & LC $_{\mathbf{5 0}}(\mu \mathrm{g} / \mathbf{m g})$ & LC $_{\mathbf{9 0}}(\boldsymbol{\mu g} / \mathbf{m g})$ \\
\hline Body & $\mathbf{1}$ & $74.9 \pm 2.92$ & \multicolumn{2}{c}{ nc } \\
\hline Hemolymph & 1 & $84.05 \pm 2.64$ & $0.656(0.626-0.687)$ & $1.108(1.054-1.172)$ \\
CTD & 0.5 & $100 \pm 0$ & $0.0252(0.023-0.027)$ & $0.065(0.061-0.070)$ \\
\hline
\end{tabular}

a Data corrected according to Scheider-Orelli's formula. Values are means of four replicates. ${ }^{\mathrm{b}}$ Lethal doses to give $50 \%$ and $90 \%$ mortality (95\% Confidence Limits).

B. majalis extracts and cantharidin were strong antifeedants against aphids, with Rhopalosiphum padi more sensitive than Myzus persicae. The antifeedant effects correlated with the CTD content of the extracts (hemolymph > body extract), with pure CTD the strongest aphid antifeedant (Table 4). The feeding behavior of the polyphagous chewing lepidopteran Spodoptera littoralis was not affected (data not shown). Previously, cantharidin showed toxicity and growth-regulation effects against Plutella xylostella moth caterpillars [51], inhibited glutathione S-transferase from Codling moth caterpillars, Cydia pomonella [52] and lepidopteran protein phosphatases [53,54]. Furthermore, CTD and several acylthiourea derivatives showed contact toxicity against the aphid Brevicoryne brassicae [55]. However, this is the first report on the antifeedant effects of CTD and CTD-rich extracts against aphids.

Table 4. Insect antifeedant effects of B. majalis extracts and cantharidin (CTD).

\begin{tabular}{cccc}
\hline \multirow{2}{*}{ Treatment } & \multirow{2}{*}{ Concentration $\left(\mu \mathrm{g} / \mathrm{cm}^{2}\right)$} & Rhopalosiphum Padi & Myzus Persicae \\
\cline { 3 - 4 } & & \multicolumn{2}{c}{ \%SI $^{\mathbf{b}}$} \\
\hline Body & $\mathbf{5 0}$ & $94.35 \pm 2.42$ & $82.75 \pm 8.28$ \\
\hline \multirow{2}{*}{ Hemolymph } & $\mathrm{EC}_{50} \mathrm{~b}$ & $6.7(4.63-9.63)$ & $14.3(8.1-25.3)$ \\
& 50 & $96.84 \pm 1.94$ & $93.23 \pm 5.0$ \\
CTD & $\mathrm{EC}_{50} \mathrm{~b}$ & $0.8(0.5-1.5)$ & $3.38(1.98-5.77)$ \\
& $50 \mathrm{~g}$ & $94.7 \pm 3.5$ & $91.50 \pm 2.31$ \\
& $\mathrm{EC}_{50} \mathrm{~b}$ & $0.098(0.031-0.3)$ & $0.211(0.05-0.91)$ \\
\hline
\end{tabular}

$\mathrm{a} \% \mathrm{SI}=(1-(\mathrm{T} / \mathrm{C})) \times 100$, where $\mathrm{T}$ and $\mathrm{C}$ are settling on treated and control leaf disks. ${ }^{\mathrm{b}} \mathrm{EC}_{50}$, effective dose to give a $50 \%$ inhibition ( $95 \%$ Confidence Limits).

The extracts and CTD were effective ixodicidal agents with similar effective doses (Table 5). CTD and CTD-rich extracts had $\mathrm{LD}_{50}$ concentrations seven times more potent than the positive control, nootkatone [56] but had similar $\mathrm{LD}_{90}$ values. 
Table 5. Effects of B. majalis extracts and cantharidin (CTD) on Hyalomma lusitanicum tick larval mortality.

\begin{tabular}{cccc}
\hline \multirow{2}{*}{ Treatment } & Mortality $^{\mathbf{a}}$ & \multicolumn{2}{c}{ Lethal Concentrations $^{\mathbf{b}}$} \\
\cline { 3 - 4 } & & $\mathbf{L C}_{\mathbf{5 0}}(\boldsymbol{\mu \mathrm { g }} / \mathbf{m g})$ & $\mathbf{L C}_{\mathbf{9 0}}(\boldsymbol{\mu g} / \mathbf{m g})$ \\
\hline Body & $81.7 \pm 0.9$ & $12.79(10.84-14.93)$ & $23.93(20.79-28.94)$ \\
\hline Hemolymph & $70.2 \pm 1.8$ & $12.25(10.65-13.94)$ & $21.05(18.74-24.47)$ \\
CTD & $90 \pm 0.1$ & $12.84(11.55-14.30)$ & $20.31(18.32-23.11)$ \\
Nootkatone $^{c}$ & - & $4.02(1.92-7.42)$ & $18.02(13.60-29.16)$ \\
\hline
\end{tabular}

a At $20 \mu \mathrm{g} / \mathrm{mg}$ cellulose. Data corrected according to Scheider-Orelli's formula. Values are means of three replicates.

${ }^{\mathrm{b}}$ Lethal doses to give $50 \%$ and $90 \%$ mortality (95\% Confidence Limits). ${ }^{\mathrm{c}}$ From Ruiz-Vázquez et al. [56].

The fact that the hemolymph and the body extracts showed similar effects suggests the presence of additional ixodicidal components in the body extract, which had the lowest CTD concentration. Chemically defended insects often contain multiple classes of toxic compounds [44]. Wang et al. (2014) [55] previously reported the acaricidal effects of CTD on Tetranychus cinnabarinus. This is the first report on the ixodicidal effects of cantharidin.

\section{Conclusions}

Our study documents that CTD is active against a diverse range of organisms including protozoa, nematodes, ticks, and insects. As such, our findings support Bravo et al.'s (2014) [36] hypothesis that Great Bustards might reduce parasite loads via the ingestion of blister beetles, a possible example of self-medication.

On a broader scale, our results (and those of other authors) showing CTD activity against a diverse range of taxa, suggest that this natural product might be developed to combat specific pests or pathogens under certain conditions. Of course, CTD is highly toxic to humans and many vertebrates [57,58], and appropriate safety precautions must be followed. That CTD is currently used in humans to treat common and molluscum warts, to remove tattoos, and as a counterirritant, and that it has commonly been used to encourage livestock breeding, implies that additional (safe) uses might be found.

\section{Materials and Methods}

\subsection{Insect Extracts}

Two hundred adult Berberomeloe majalis of mixed sex (males averaged $22.3 \pm 0.3 \mathrm{~mm}$ and $490 \pm 34.1 \mathrm{mg}$; females $30.3 \pm 1.4 \mathrm{~mm}$ and $1234 \pm 138.3 \mathrm{mg}$ ) were collected in Central Spain (Finca La Garganta, Ciudad Real) in March 2015. Insects were frozen at $-20^{\circ} \mathrm{C}$ until use. To obtain hemolymph, we cut the terminal abdomens and allowed hemolymph to drip into a vial. The resulting hemolymph $(4.8 \mathrm{~mL})$ was extracted with dichloromethane (DCM) $(10 \mathrm{~mL}, 3$ times) and the solvent evaporated to give an extract of beetle hemolymph $(20 \mathrm{mg})$. The remaining insect bodies ( $172 \mathrm{~g}$ of combined males and females) were macerated with DCM ( $400 \mathrm{~mL}, 3$ times) at room temperature, filtered, and the solvent evaporated to give $44 \mathrm{~g}$ of body extract.

\subsection{Cantharidin Quantification}

We analyzed the above extracts via GC-MS (Thermo Finnigan Trace GC 2000 coupled with a Trace MS mass selective detector). The chromatographic conditions were controlled using Xcalibur software version 1.2 (Thermo Finnigan, San Jose, CA, USA). The GC column was a SLB-5 ms ( $30 \mathrm{~m}$, $60.32 \mathrm{~mm}, 0.25 \mu \mathrm{m}$, Supelco Analytical, Bellefonte, PA, USA). The flow rate of helium was $0.8 \mathrm{~mL} / \mathrm{min}$. The injection volume was $1 \mathrm{~mL}$ in splitless mode for $2 \mathrm{~min}$. Injector conditions were $250^{\circ} \mathrm{C}$ in constant flow mode. The column oven had an initial temperature of $50^{\circ} \mathrm{C}$ for two minutes. The subsequent temperature was programmed at a heating rate of $10^{\circ} \mathrm{C} / \mathrm{min}$ to $310^{\circ} \mathrm{C}$. The final temperature was held isothermally for $5 \mathrm{~min}$. Total run time was $30 \mathrm{~min}$. Cantharidin (CTD) detection was performed by selected ion monitoring (SIM), registering $\mathrm{m} / \mathrm{z}=128$ (= the majority ion of CTD's mass spectra). 
CTD identification was performed by comparison with mass spectra available in the NIST MS search 2.0 library. The extracts were dissolved in DCM and the concentrations injected were 0.1 and $0.5 \mathrm{mg}$ of extract $/ \mathrm{mL} \mathrm{DCM}$ for the hemolymph and body extracts, with an injection volume of $1 \mathrm{~mL}$. Confirmation and quantification were achieved with the retention time and calibration curves (range: $0.015-48 \mathrm{mg} / \mathrm{mL}$, slope: $476.401, \mathrm{r}^{2}=0.999$ ) obtained from the injection of CTD standard purchased from Sigma-Aldrich (St. Louis, MO, USA).

\subsection{Bioassays}

In all bioassays we tested various doses of three primary preparations: (1) Extract of beetle hemolymph. (2) Extract of beetle bodies. (3) 99\% pure CTD (Sigma-Aldrich, St. Louis, MO, USA).

\subsection{Antiprotozoal Activity}

Antiprotozoal activity was evaluated on the metronidazole-sensitive Trichomonas vaginalis JH31A no.4 isolate (American Type Culture Collection, (ATCC)). The flagellates were cultured in a trypticase-yeast extract-maltose modified medium supplemented with $10 \%$ heat-inactivated fetal bovine serum (FBS) and antibiotic solutions at $37^{\circ} \mathrm{C}$ and $5 \% \mathrm{CO}_{2}$. Assays were carried out in glass tubes containing $10^{5}$ trophozoites $/ \mathrm{mL}$. After $5-6 \mathrm{~h}$ of seeding, extracts (1), (2) or CTD were added to log-phase growth cultures at several concentrations $(500,250,100,50,25$ and $10 \mu \mathrm{g} / \mathrm{mL}$ for extracts (1) and (2); 100, 50, 25, 10, 5 and $1 \mu \mathrm{g} / \mathrm{mL}$ for CTD). The tubes were incubated for $24 \mathrm{~h}$ at $37^{\circ} \mathrm{C}$ and $5 \% \mathrm{CO}_{2}$. The trichomonacidal activity was obtained by a fluorimetric method using resazurin (Sigma-Aldrich) as previously described $[59,60]$. The experiments were performed at least two times in triplicate. GI $_{50}$ values, as well as the $95 \%$ CI were calculated by Probit analysis (SPSS v.20, IBM, Armonk, NY, USA).

\subsection{Nematicidal Activity}

We tested the toxicity of our three preparations against 2nd stage juveniles (J2) of Meloidogyne javanica previously maintained on Lycopersicon esculentum plants (var. "Marmande") in pot cultures at $25 \pm 1{ }^{\circ} \mathrm{C}$ and $>70 \% \mathrm{RH}$. The experiments were carried out in 96-well microplates (Becton, Dickinson), as described per Andrés et al., (2012) [61]. The three preparations were tested at initial concentrations of 1.0 and $0.5 \mathrm{mg} / \mathrm{mL}$ (final concentration in the well) and diluted serially if necessary. The number of dead juveniles was recorded after $72 \mathrm{~h}$. All treatments were replicated four times. The data were determined as mortality percentage corrected according to Scheider-Orelli's formula. Effective lethal doses $\left(\mathrm{LC}_{50}\right.$ and $\mathrm{LC}_{90}$ ) were calculated for the active pure compounds by Probit analysis (five serial dilutions, $0.5-0.01 \mathrm{mg} / \mathrm{mL}$ ).

\subsection{Insect Bioassays}

Spodoptera littoralis, Myzus persicae and Rhopalosiphum padi colonies were reared on an artificial diet, bell pepper (Capsicum annuum) and barley (Hordeum vulgare) respectively, and maintained at $22 \pm 1{ }^{\circ} \mathrm{C}$, $>70 \%$ relative humidity with a photoperiod of $16: 8 \mathrm{~h}(\mathrm{~L}: \mathrm{D})$ in a growth chamber. Choice antifeedant bioassays were conducted in Petri dishes with newly emerged S. littoralis sixth instar larvae (at least 10 replicates with 2 insects each to give a SE $<10$ ) or $2 \times 2 \mathrm{~cm}$ plastic boxes with adults $(24-48 \mathrm{~h}$ old) of the aphids M. persicae and R. padi (20 replicates with 10 insects each). Feeding or settling inhibition on treated (10 $\mu \mathrm{L}$ of extract or CTD solution) and untreated (10 $\mu \mathrm{L}$ of solvent) leaf disks of the host plant $(\% \mathrm{FI}$ or $\% \mathrm{SI})$ were calculated as $\% \mathrm{FI}=(1-(\mathrm{T} / \mathrm{C})) \times 100$, where $\mathrm{T}$ and $\mathrm{C}$ are the consumption of treated and control leaf disks, respectively, or as $\% \mathrm{SI}=(1-10(\% \mathrm{~T} / \% \mathrm{C})) \times 100$ where $\% \mathrm{C}$ and $\% \mathrm{~T}$ are percent aphids settled on control and treated leaf disks, respectively, as described [62]. The antifeedant effects (\%FI/\%SI) were analyzed for significance by the non-parametric Wilcoxon signed-rank test. $\mathrm{EC}_{50}$ (effective dose to obtain $50 \%$ feeding inhibition) were determined for extracts and CTD (four serial dilutions, $10-1$ or $5-0.5 \mathrm{mg} / \mathrm{mL}$ ) with $\% \mathrm{FI} / \% \mathrm{SI}$ values $>75 \%$ from a linear regression analysis (\%FI/\%SI values on log (Dose)) (statistical package: www.statgraphics.com). 


\subsection{Ixodicidal Activity}

Hyalomma lusitanicum engorged female ticks were collected in central Spain (Finca La Garganta, Ciudad Real) from their host (deer) and maintained at $22-24{ }^{\circ} \mathrm{C}$ and $70 \% \mathrm{RH}$ in a growth chamber until oviposition and egg hatch. Resulting larvae (4-6 weeks old) were used for the bioassays. Briefly, $50 \mu \mathrm{L}$ test solution were added to $25 \mathrm{mg}$ of powdered cellulose at different concentrations and the solvent evaporated. For each test, three replicates with 20 larvae each were used. Larval mortality was checked after $24 \mathrm{~h}$ of contact with the treated cellulose in the environmental conditions described [56], using a binocular magnifying glass. The mortality data shown have been corrected with respect to the control according to Schneider-Orelli's formula. Effective lethal doses $\left(\mathrm{LC}_{50}\right.$ and $\left.\mathrm{LC}_{90}\right)$ were calculated by Probit Analysis (5 serial dilutions, STATGRAPHICS Centurion XVI, version 16.1.02).

Author Contributions: Conceptualization, D.W.W. and A.G.-C.; methodology, M.F.A., R.A.M.-D., A.I.-E., A.S.O. and A.G.-C.; investigation, M.F.A., R.A.M.-D., A.I.-E., A.S.O. and A.G.-C.; resources, A.G.-C.; writing - original draft preparation, D.W.W. and A.G.-C..; writing-review and editing, D.W.W. and A.G.-C.; R.A.M.-D., M.F.A., A.S.O. and A.I.-E.; supervision, A.G.-C.; funding acquisition, A.G.-C.

Funding: This research was funded by MINECO/FEDER, Spain, Grant no. CTQ2015-64049-C3-1-R; Ministerio de Economia y Competitividad, Spain (MINECO/FEDER), Grant no. CGL2017-87206-P.

Acknowledgments: The authors are especially grateful to J.M. Tercero (Villamagna SA) and his Grace the Duke of Westminster for providing B. majalis and H. lusitanicum.

Conflicts of Interest: The authors declare no conflict of interest.

\section{References}

1. Gathercoal, E.N.; Wirth, E.H. Pharmacognosy; Lea and Febiger: Philadelphia, PA, USA, 1936; pp. 1-852.

2. Wang, G.S. Medical uses of mylabris in ancient China and recent studies. J. Ethnopharmacol. 1989, 26, 147-162. [CrossRef]

3. Wilson, C.R. Methods for Analysis of Gastrointestinal Toxicants. In Comprehensive Toxicology, 2nd ed.; Hooser, S., Mc-Queen, C., Eds.; Elsevier Academic Press: London, UK, 2010; pp. 145-152.

4. Moed, L.; Shwayder, T.A.; Chang, M.W. Cantharidin revisited: A blistering defense of an ancient medicine. Arch. Dermatol. 2001, 137, 1357-1360. [CrossRef] [PubMed]

5. Pajovic, B.; Radosavljevic, M.; Radunovic, M.; Radojevic, N.; Bjelogrlic, B. Arthropods and their products as aphrodisiacs-Review of literature. Eur. Rev. Med. Pharmaco. 2012, 16, 539-547.

6. James, P.; Thorpe, N. Ancient Inventions; Ballantine Books; The Random House Publishing Group: New York, NY, USA, 1995; pp. 1-672.

7. Ford, P.; Howell, M. The Beetle of Aphrodite and other Medical Mysteries; Random House: New York, NY, USA, 1985; pp. 1-358.

8. Schaeffer, N. The Marquis de Sade: A Life; Harvard University Press: Cambridge, MA, USA, 2000; pp. 1-557.

9. Robiquet, M. Expériences sur les cantharides. Annales de Chimie 1810, 76, 302-322.

10. Aggrawal, A. Spanish Fly (Cantharides). In Textbook of Forensic Medicine and Toxicology; Avichal Publishing Company: New Delhi, India, 2014; p. 652.

11. Blood, D.C.; Studdert, V.P.; Gay, C.C. Saunders Comprehensive Veterinary Dictionary, 3rd ed.; Elsevier: Philadelphia, PA, USA, 2007; pp. 1-2172.

12. Anon. Cantharide. In Farlex Partner Medical Dictionary; Farlex: Huntingdon Valley, PA, USA, 2012. Available online: http://medical-dictionary.thefreedictionary.com/ (accessed on 31 January 2017).

13. Taberner, P.V. Aphrodisiacs: The Science and the Myth; Springer Science \& Business Media: Bristol, UK, 2012; pp. 1-278.

14. Puerto-Galvis, C.E.; Vargas-Méndez, L.Y.; Kouznetsov, V.V. Cantharidin-Based Small Molecules as Potential Therapeutic Agents. Chem. Biol. Drug Des. 2013, 82, 477-499. [CrossRef] [PubMed]

15. Karras, D.J.; Farrell, S.E.; Harrigan, R.A.; Henretig, F.M.; Gealt, L. Poisoning from "Spanish Fly" (cantharidin). Am. J. Emerg. Med. 1996, 14, 478-483. [CrossRef]

16. Ghoneim, K. Cantharidin toxicosis to animal and human in the world: A review. Stand. Res. J. Toxicol. Environ. Health Sci. 2013, 1, 1-16. 
17. Cotovio, P.; Silva, C.; Marques, M.G.; Ferrer, F.; Costa, F.; Carreira, A.; Campos, M. Acute kidney injury by cantharidin poisoning following a silly bet on an ugly beetle. Clin. Kidney J. 2013, 6, 201-203. [CrossRef]

18. Schmitz, D.G. Overview of Cantharidin Poisoning (Blister Beetle Poisoning). In The Merck Veterinary Manual; Aiello, S.E., Moses, M.A., Eds.; Merck Sharp \& Dohme: Kenilworth, NJ, USA, 2013. Available online: http://www.merckvetmanual.com/ (accessed on 31 January 2017).

19. Nickolls, L.C.; Teare, D. Poisoning by cantharidin. Br. Med. J. 1954, 2, 384-1386. [CrossRef]

20. Froberg, B.A. Animals. In Criminal Poisoning: Clinical and Forensic Perspectives; Jones \& Bartlett: Burlington, MA, USA, 2010; pp. 39-48.

21. Al-Rumikan, A.; Al-Hamdan, N.A. Indirect cantharidin food poisoning caused by eating wild birds. Saudi Epidemiol. Bulll. 1999, 6, 25-26.

22. Penrith, M.L.; Naudé, T.W. Mortality in chickens associated with blíster beetle consumption. J. S. Afr. Vet. Assoc. 1996, 67, 97-99.

23. Rockett, J.; Bosted, S. Veterinary Clinical Procedures in Large Animal Practices; Cengage Learning: Boston, MA, USA, 2015; pp. 1-672.

24. Honkanen, R.E. Cantharidin, another natural toxin that inhibits the activity of serine/threonine protein phosphatases types 1 and $2^{\mathrm{a}}$. FEBS Lett. 1993, 330, 283-286. [CrossRef]

25. Baba, Y.; Hirukawa, N.; Sodeoka, M. Optically active cantharidin analogues possessing selective inhibitory activity on Ser/Thr protein phosphatase 2B (calcineurin): Implications for the binding mode. Bioorgan. Med. Chem. 2005, 13, 5164-5170. [CrossRef]

26. Bologna, M.A.; Oliverio, M.; Pitzalis, M.; Mariottini, P. Phylogeny and evolutionary history of the blister beetles (Coleoptera, Meloidae). Mol. Phylogenet. Evol. 2008, 48, 679-693. [CrossRef]

27. Carrel, J.E.; Eisner, T. Cantharidin: Potent feeding deterrent to insects. Science 1974, 183, 755-757. [CrossRef] [PubMed]

28. Nikbakhtzadeh, N.R.; Dettner, K.; Boland, W.; Gäde, G.; Dötterle, S. Intraspecific transfer of cantharidin within selected members of the family Meloidae (Insecta: Coleoptera). J. Insect. Physiol. 2007, 53, 890-899. [CrossRef]

29. Eisner, T.; Conner, J.; Carrel, J.E.; McCormick, J.P.; Slagle, A.J.; Gans, C.; O’Reilly, J.C. Systemic retention of ingested cantharidin by frogs. Chemoecology 1990, 1, 57-62. [CrossRef]

30. Bartram, S.; Boland, W. Chemistry and ecology of toxic birds. ChemBioChem 2001, 2, 809-811. [CrossRef]

31. Wirtz, W.O.; Austin, D.H.; Dekle, G.W. Food habits of the common long-nosed armadillo Dasypus movemcinctus in Florida, 1960-1961. In Evolution and Ecology of Armadillos, Sloths, and Vermilinguas; Montgomery, G.G., Ed.; Smithsonian Institution Press: Washington, DC, USA, 1985; pp. 439-451.

32. Larson, N.P. The common toad as an enemy of blíster beetles. J. Econ. Entomol. 1943, 36, 480. [CrossRef]

33. Kilham, L. Use of blíster beetle in bill-sweeping by White-brested Nuthatch. Auk Ornithol. Adv. 1971, 88, 175-176.

34. Percino-Daniel, N.; Buckley, D.; García-París, M. Pharmacological properties of blister beetles (Coleoptera: Meloidae) promoted their integration into the cultural heritage of native rural Spain as inferred by vernacular names diversity, traditions, and mitochondrial DNA. J. Ethnopharmacol. 2013, 147, 570-583. [CrossRef]

35. Sánchez-Barbudo, I.S.; Camarero, P.R.; García-Montijano, M.; Mateo, R. Possible cantharidin poisoning of a great bustard (Otis tarda). Toxicon 2012, 59, 100-103. [CrossRef] [PubMed]

36. Bravo, C.; Bautista, L.M.; García-París, M.; Blanco, G.; Alonso, J.C. Males of a Strongly Polygynous Species Consume More Poisonous Food than Females. PLoS ONE 2014, 9, e111057. [CrossRef] [PubMed]

37. Bailey, T.A. Diseases and Medical Management of Houbara Bustards and other Otididae; Emirates Printing Press LLC: Dubai, UAE, 2008; pp. 1-494.

38. Silvanose, C.; Samour, J.; Naldo, J.; Bailey, T.A. Oro-pharyngeal protozoa in captive bustards: Clinical and pathological considerations. Avian. Pathol. 1998, 27, 526-530. [CrossRef]

39. Alonso, J.C.; Palacín, C. Avutarda-Otis tarda. In Enciclopedia Virtual de los Vertebrados Españoles; Salvador, A., Morales, M.B., Eds.; Museo Nacional de Ciencias Naturales: Madrid, Spain, 2015. Available online: http://www.vertebradosibericos.org/ (accessed on 31 January 2017).

40. Cordero del Campillo, M.; Castañón-Ordóñez, L.; Reguera-Feo, A. Índice Catálogo de Zooparásitos Ibéricos, 2nd ed.; Universidad de León, Secretariado de Publicaciones: León, Spain, 1994; pp. 1-650. 
41. McCormick, J.P.; Carrel, J.E. Cantharidin biosynthesis and function in meloid beetles. In Pheromone Biochemistry; Prestwich, G.D., Bloomquist, H.F., Eds.; Harcourt, Brace, \& Jovanovich: Orlando, FL, USA, 1987; pp. 307-350.

42. Carrel, J.E.; McCairel, M.H.; Slagle, A.J.; Doom, J.P.; Brill, J.; McCormick, J.P. Cantharidin production in a blister beetle. Experientia 1993, 49, 171-174. [CrossRef]

43. Mebs, D.; Pogoda, W.; Schneider, M.; Kauert, G. Cantharidin and demethylcantharidin (palasonin) content of blister beetles (Coleoptera: Meloidae) from southern Africa. Toxicon 2009, 53, 466-468. [CrossRef] [PubMed]

44. Whitman, D.W. Allelochemical interactions among plants, herbivores, and their predators. In Novel Aspects of Insect-Plant Interactions; Barbosa, P., Letrourneau, D., Eds.; John Wiley: New York, NY, USA, 1988; pp. 11-64.

45. De Brum Vieira, P.; Brandt Giordani, R.; Macedo, A.J.; Tasca, T. Natural and synthetic compound anti-Trichomonas vaginalis: An update review. Parasitol. Res. 2015, 114, 1249-1261. [CrossRef]

46. Yahya, M.; Fatemeh, G.; Abdolhosein, D.; Zohreh, S.; Zuhair, H. Effect of cantharidin on apoptosis of the Leishmania major and on parasite load in BALB/c mice. Res. J. Parasitol. 2013, 8, 14-25.

47. Ghaffarifar, F. Leishmania major: In vitro and in vivo anti-leishmanial effect of cantharidin. Exp. Parasitol. 2010, 126, 126-129. [CrossRef]

48. Bajsa, J.; McCluskey, A.; Gordon, C.P.; Stewart, S.G.; Sahu, R.; Duke, S.O.; Tekwan, B.L. The antiplasmodial activity of norcantharidin analogs. Bioorg. Med. Chem. Lett. 2010, 20, 6688-6695. [CrossRef] [PubMed]

49. Campbell, B.E.; Tarleton, M.; Gordon, C.P.; Sakoff, J.A.; Gilbert, J.; McCluskey, A.; Gasser, R.B. Norcantharidin analogues with nematocidal activity in Haemonchus contortus. Bioorg. Med. Chem. Lett. 2011, 21, 3277-3281. [CrossRef]

50. Campbell, B.E.; Hofmann, A.; McCluskey, A.; Gasser, R.B. Serine/threonine phosphatases in socioeconomically important parasitic nematodes-prospects as novel drug targets? Biotechnol. Adv. 2011, 29, 28-39. [CrossRef]

51. Huang, Z.; Zhang, Y. Chronic sublethal effects of cantharidin on the diamondback moth Plutella xylostella (lepidoptera: Plutellidae). Toxins 2015, 7, 1962-1978. [CrossRef]

52. Yang, X.; Zhang, Y. Characterization of glutathione S-transferases from Sus scrofa, Cydia pomonella and Triticum aestivum: Their responses to cantharidin. Enzyme Microb. Technol. 2015, 69, 1-9. [CrossRef] [PubMed]

53. Chen, X.; Lü, S.; Zhang, Y. Characterization of protein phosphatase 5 from three lepidopteran insects: Helicoverpa armigera, Mythimna separata and Plutella xylostella. PLoS ONE 2014, 9, e97437. [CrossRef] [PubMed]

54. Chen, X.; Liu, J.; Zhang, Y. Cantharidin impedes the activity of protein serine/threonine phosphatase in Plutella xylostella. Mol. BioSyst. 2014, 10, 240-250. [CrossRef]

55. Wang, M.; Nan, X.; Feng, G.; Yu, H.; Hu, G.; Liu, Y. Design, synthesis and bioactivity evaluation of novel acylthiourea derivatives of cantharidin. Ind. Crop. Prod. 2014, 55, 11-18. [CrossRef]

56. Ruiz-Vásquez, L.; Olmeda, A.S.; Zúñiga, G.; Villarroel, L.; Echeverri, L.F.; González-Coloma, A.; Reina, M. Insect antifeedant and ixodicidal compounds from Senecio adenotrichius. Chem. Biodivers. 2017, 14, 1612-1880. [CrossRef] [PubMed]

57. Till, J.S.; Majmudar, B.N. Cantharidin poisoning. South. Med. J. 1981, 74, 444-447. [CrossRef]

58. Polettini, A.; Crippa, O.; Ravagli, A.; Saragoni, A. A fatal case of poisoning with cantharidin. Forensic. Sci. Int. 1992, 56, 37-43. [CrossRef]

59. Martínez-Díaz, R.A.; Ibáñez-Escribano, A.; Burillo, J.; de las Heras, L.; del Prado, G.; Agulló-Ortuño, M.T.; Julio, L.F.; González-Coloma, A. Trypanocidal, trichomonacidal and cytotoxic components of cultivated Artemisia absinthium Linnaeus (Asteraceae) essential oil. Mem. Inst. Oswaldo Cruz. 2015, 110, 639-699. [CrossRef] [PubMed]

60. Ibáñez-Escribano, A.; Meneses Marcel, A.; Machado Tugores, Y.; Nogal Ruiz, J.J.; Arán Redó, V.J.; Escario García-Trevijano, J.A.; Gómez Barrio, A. Validation of a modified fluorimetric assay for the screening of trichomonacidal drugs. Mem. Inst. Oswaldo Cruz. 2012, 107, 637-643. [CrossRef]

61. Andrés, M.F.; González-Coloma, A.; Sanz, J.; Burillo, J.; Sainz, P. Nematocidal activity of essential oils: A review. Phytochem. Rev. 2012, 11, 371-390. [CrossRef]

62. Burgueño-Tapia, E.; Castillo, L.; González-Coloma, A.; Joseph-Nathan, P. Antifeedant and phytotoxic activity of the sesquiterpene p-benzoquinone perezone and some of its derivatives. J. Chem. Ecol. 2008, 34, 766-771. [CrossRef] [PubMed]

(C) 2019 by the authors. Licensee MDPI, Basel, Switzerland. This article is an open access article distributed under the terms and conditions of the Creative Commons Attribution (CC BY) license (http://creativecommons.org/licenses/by/4.0/). 